\title{
ANALISIS KEBIJAKAN PENDIDIKAN DALAM PENYIAPAN SARANA DAN PRASARANA PADA PERENCANAAN PEMBELAJARAN TATAP MUKA DI SMA KRISTEN BARANA'
}

\author{
Warya Awersendi S. Rumbiak ${ }^{1}$, Witarsa Tambunan ${ }^{2}$
}

1Mahasiswa Magister Administrasi Pendidikan PPs-UKI, Jakarta, Indonesia, ${ }^{2}$ Dosen Magister Administrasi Pendidikan PPs -UKI, Jakarta Indonesia

e-mail: witarsa.oke@gmail.com

\begin{tabular}{l|l|l} 
Received : Januari, 2021 & Accepted : Januari, 2021 & Published : Januari, 2021
\end{tabular}

\begin{abstract}
Covid 19 pandemic that occurred globally had an impact in the world of education to rethink about ways of school organization related to face-to-face learning preparation. The purpose of this paper is to analyze educational policies in the preparation of facilities and infrastructure as a strategy or effort to prepare faceto-face learning at Barana Christian Senior High School ', North Toraja district. This analysis uses a qualitative approach with descriptive research in which the data collection techniques are using school observations and literature review. The results of this study provide information to policy makers in schools in preparing appropriate facilities and infrastructure and planning face-to-face learning strategies that are effective and efficient, especially in the new normal era. The results of this study are expected to be researched further.
\end{abstract}

Keywords: education policy analysis, facilities, face-to-face learning process

\begin{abstract}
Abstrak
Wabah Pandemi Covid 19 yang terjadi secara global memberi dampak dalam dunia pendidikan untuk memikirkan kembali upaya organisasi sekolah terkait penyiapan pembelajaran tatap muka. Tujuan penulisan ini untuk menganalisis kebijakan pendidikan dalam penyiapan sarana dan prasarana sebagai strategi atau upaya persiapan pembelajaran tatap muka di SMA Kristen Barana', kabupaten Toraja Utara. Adapun analisis ini menggunakan pendekatan kualitatif dengan penelitian deskriptif yang mana teknik pengumpulan datanya dengan observasi di sekolah, dan telaah pustaka (literature review). Hasil penelitian ini memberikan informasi kepada pembuat kebijakan di sekolah dalam mempersiapkan sarana dan prasarana yang tepat guna dan perencanaan strategi pembelajaran tatap muka yang efektif dan efisien, khususnya di masa new normal. Hasil kajian ini diharapkan untuk dapat diteliti lebih lanjut.
\end{abstract}

Kata Kunci: analisis kebijakan pendidikan, sarana prasarana, pembelajaran tatap muka

Citation: Rumbiak, W. A. S., \& Tambunan, W. (2021). ANALISIS KEBIJAKAN PENDIDIKAN DALAM PENYIAPAN SARANA DAN PRASARANA PADA PERENCANAAN PEMBELAJARAN TATAP MUKA DI SMA KRISTEN BARANA'. Jurnal Manajemen Pendidikan, 10(1), 28-36. Retrieved from http://ejournal.uki.ac.id/index.php/imp/article/view/3264 


\section{PENDAHULUAN}

Kondisi pendidikan di Indonesia mulai awal tahun ajaran 2020 sampai pada akhir 2021 telah mengalami transformasi sistem pendidikan yang luar biasa selama pandemi Covid 19 yang melanda dunia secara global. Penerapan phisycal dan social distancing membuat sistem belajar berubah atau mengalami transformasi sistem, dari model belajar tatap muka dikelas menjadi pembelajaran daring, pertemuan secara virtual dengan penggunaan aplikasi. Dalam situasi sepanjang tahun tersebut memberikan tantangan bagi guru dan siswa dalam melaksankan proses pembelajaran jarak jauh (PJJ). Tantangan bagi guru adalah bagaimana harus mempersiapkan materi dan metode pembelajaran dalam rangka transfer ilmu kepada siswa secara efektif dan efisien melihat keberagaman kecerdasan siswa, dan gaya belajar siswa yang beragam pula. Dalam tantangan ini, menurut Eli Novianty dkk $(2020 ; 203)$ terdapat peluang bagi guru untuk mempelajari teknologi audio visual, dan berinovasi memanfaatkan teknologi dan aplikasi serta memikirkan model pembelajaran yang efektif. Di sisi lain, tantangan bagi siswa adalah bagaimana harus memiliki smartphone/android dan pulsa data, dan belajar serta melatih diri dalam menggunakan aplikasi pembelajaran yang diarahkan oleh guru. Tantangan yang dialami siswa merupakan tantangan bagi orang tua dalam menyediakan sarana smartphone dengan membelikan buat anaknya beserta pembiayaan pulsa data. Bagi keluarga yang berada, tentunya ini merupakan hal yang tidak sulit untuk direalisasikan, namun sebaliknya bagi keluarga yang berkekurangan tentunya ini merupakan hal yang sulit, setengah mati untuk diadakan.

Proses pembelajaran jarak jauh dan tatap muka di unit sekolah sudah tentu bergantung pada keputusan dan kebijakan tertinggi pemerintah melalui lembaga Kementerian Pendidikan dan Kebudayaan, yaitu learning from home khusus bagi sekolah-sekolah yang berada dalam zona merah dan zona kuning seperti dalam jumpa pers resmi 137/SiPres/A6/VI/2020, sedangkan di zona hijau sekolah dapat melakukan proses belajar tatap muka dengan protokol kesehatan yang ketat, contohnya wajib tes antigen, menggunakan masker, melakukan social dan phisycal distancing dikelas dengan pengaturan meja dan kursi secara proporsional (Siti \&Ahmad, 2020;403). Tidak cukup sampai disana, namun penerapan protokol yang ketat harus diberlakukan dalam lingkungan sekolah, di dalam kelas, kantor, bahkan laboratorium sekolah. Dengan kurang maksimalnya sarana dan prasarana, baik bagi siswa, maupun persiapan unit sekolah dalam mempersiapkan proses pembelajaran di era new normal, maka dapat berdampak pada persiapan pembelajaran tatap muka itu sendiri. Nurochim dan Siti $(2020 ; 156)$ mengusulkan sekalipun di masa new normal dan situasi pandemi yang masih ada diperlukan rancangan program yang tepat dalam melihat dinamika yang terjadi khususnya dalam proses pembelajaran tatap muka. Analisis kebijakan pendidikan sangat esensial dilakukan oleh pemegang kebijakan di sekolah secara khusus menanggapi Panduan yang diterbitkan pemerintah tentang Penyelenggaraan Pembelajaran di Masa Pandemi Coronavirus Disease 2019 (Covid-19) yang tertuang dalam Surat Keputusan Bersama (SKB) Menteri Pendidikan dan Kebudayaan, Menteri Dalam Negeri, Menteri Kesehatan, dan Menteri Agama. Inti dari panduan ini dijelaskan oleh Menteri Pendidikan dan Kebudayaan, mas Nadiem Makarim yang mengungkapkan bahwa pemerintah mendorong proses akselerasi pembelajaran tatap muka (PTM) yang mana dengan tetap menjalankan protokol kesehatan.

Dalam menindaklanjuti SKB tersebut, sekolah-sekolah di Kabupaten Toraja Utara yang berada dalam zona hijau seperti SMA Kristen Barana' sangat perlu mengambil keputusan bersama antara Gugus Tugas Penanganan Covid Kabupaten, Dinas Pendidikan Daerah, dan Kepala Sekolah dalam mempersiapkan sistem dan proses pembelajaran pada tahun ajaran baru 2021/2022 di era new normal. Proses analisis kebijakan pendidikan oleh kepala Sekolah dan para wakil-wakil dalam proses persiapan PTM menjadi satu hal yang sangat esensial, khususnya dalam menyiapkan sarana dan prasarana di SMA Kristen Barana' secara khusus, melihat model sekolahnya berasrama. Kurangnya persiapan dan penyiapan sarana dan prasarana di lingkungan sekolah dapat mengakibatkan tidak terlaksananya proses pembelajaran tatap muka di sekolah.

Warya Awersendi S. Rumbiak, Witarsa Tambunan 
Maka dari itu, sesungguhnya analisis kebijakan pendidikan di SMA Kristen Barana' secara bersama oleh pemegang dan pemangku kebijakan dalam memikirkan, menguraikan, mengidentifikasi proses penyiapan pembelajaran secara bersama harus dilakukan.

\section{Analisis Kebijakan Pendidikan}

Membahas mengenai kebijakan, kebijakan berasal dari kata "policy". Policy secara etimologis dari bahasa Yunani, Sansekerta dan Latin. "Policy" dalam bahasa Yunani adalah "polis" berarti negara kota, sedangkan bahasa Sansekerta "pur" berarti kota. Kata ini berkembang dalam bahasa Latin "politic" yang berarti negara. Joko Widodo(2020;90) menjelaskan bahwa analisis kebijakan adalah suatu prosedur untuk menghasilkan informasi mengenai masalah-masalah kemasyarakatan berikut tindakan pemecahannya. Analisis Kebijakan (Policy Analisys) Dalam Kamus Besar Bahasa Indonesia (2008) didefinisikan sebagai: Penyelidikan terhadap suatu peristiwa (berupa karangan atau perbuatan)guna mengetahui kondisi faktualnya (sebab-musabab, duduk perkaranya) Penguraian suatu pokok atas berbagai telaah atas bagian itu sendiri atau hubungan antar unit untuk memperoleh pemahaman yang tepat dan menyeluruh.

Sedangkan menurut Witarsa merujuk pendapat Quade (1988-48) dalam materi kuliah Analisis Kebijakan Pendidikan, mengemukakan analisis sebagai sebuah proses, terdiri: (1)Formulation sebagai clarifying dan constraining the problem serta determining the obyectives. (2)Search merupakan identifying, designing dan screening the alternatives, (3)Forecasting adalah predicting the future environment atau operational context, (4)Modeling adalah building dan using models untuk determine the impact, (5)Evaluating adalah comparing dan ranking the alternatives

Proses menganalisis kebijakan merupakan suatu hal yang penting karena merupakan kebutuhan bagi ilmuwan pendidikan, untuk memahami studi mengenai kebijakan publik (public policy) khususnya kebijakan pendidikan (educational policy). Witarsa (2021; ppt 2) menjelaskan bahwa kepentingan kebijakan ini erat kaitannya dengan peran yang diharapkan dari ilmuwan pendidikan, tidak saja nantinya diharapkan sebagai seorang perumus kebijakan pendidikan yang berkualitasapabila ilmuwan pendidikan terlibat dalam proses pembuatan kebijakan (policy maker)- akan tetapi lebih dari sekadar itu, ilmuwan pendidikan diharapkan akan memberikan peran yang besar dalam memberikan koreksi terhadap berbagai kesalahan-kesalahan/ketidaktepatan dalam perumusan. Dalam meningkatkan mutu pendidikan maka setiap lembaga harus memiliki sistem yang berkualitas yang merupakan bentuk kebijakan kepala sekolah yang memiliki kompentensi profesional. Indah Hari dan Nasution (2020;47) mengungkapkan bahwa Kepala sekolah sangat berperan aktif dalam membawa perubahan pada lembaga pendidikan untuk lebih baik dengan mempengaruhi segala komponen pendidikan seperti guru, peserta didik dan masyarakat. Kebijakan ada di tangan pimpinan sekolah dan para wakil-wakilnya.

Analisis kebijakan pendidikan sangat penting dalam mencapai tujuan pendidikan dalam mencerdaskan kehidupan bangsa dan negara. Pendidikan sebagai satu bagian dari dimensi kehidupan manusia yang mana memiliki pengaruh besar bagi kehidupan manusia secara personal maupun dalam komunitas sosial. Upaya yang dilakukan oleh pemerintah atau publik yang memiliki kepedulian terhadap pendidikan perlu dicermati, sebab dampaknya sangat luas bagi kehidupan manusia dalam jangka pendek dan jangka panjang. Analisis kebijakan pendidikan perlu didasarkan pada suatu prinsip objektif, tidak hanya untuk menyalahkan kebijakan pendidikan oleh pemerintah yang sedang berkuasa, atau pihak lain sebagai penyelenggara pendidikan namun memberi gambaran yang memungkinkan berupa perbaikan kebijakan pendidikan yang dilakukan oleh pemerintah atau penyelenggara pendidikan. Hal ini tentu saja memerlukan suatu pendekatan ilmiah yang objektif dan akurat. Itulah sebabnya analisis kebijakan pendidikan menjadi penting guna memahami dan memperbaiki kebijakan apabila hasil analisis menunjukkan konsekuensi yang belum sesuai dengan rencana yang diharapkan.

Sebagai pengambil keputusan tidak cukup hanya dengan kemampuan mengetahui dan menguasai berbagai isu dan masalah pendidikan yang relevan baik secara internal, eksternal maupun lintas sektoral. Para analisis kebijakan pendidikan dituntut untuk menguasai teknik penelitian dan 
pengembangan kebijakan pendidikan. Analisis kebijakan pendidikan dalam mempersiapkan pembelajaran tatap muka melalui sarana dan prasarana adalah sangat penting, guna membantu menentukan pilihan tepat atas suatu tindakan penyiapan sarana dan prasarana yang mana akan berpengaruh pada kesiapan dan proses pembelajaran tatap muka itu sendiri. Proses analisis kebijakan yang dilakukan sekolah dan pemerintah tentu bertujuan dan berfungsi untuk membantu pemegang kebijakan dalam mengambil keputusan, khususnya dalam mengidentifikasi dan mempersiapkan sarana dan prasarana yang tepat dalam persiapan pembelajaran tatap muka.

Berbicara tentang fungsi analisis, analisis mempunyai fungsi untuk mengumpulkan data-data yang terdapat pada suatu lingkungan tertentu. Selain itu, analisis dapat diterapkan di berbagai jenis lingkungan dan keadaan. Analisis akan lebih optimal dipergunakan dalam keadaan kritis dan untuk keadaan yang membutuhkan strategi. Karena analisis dapat mengetahui secara mendetail tentang keadaan lingkungan saat ini. Proses analisis kebijakan pendidikan tentu berkaitan dengan isu yang berkembang dan mempengaruhi dunia pendidikan. Isu yang di maksud adalah terkait dengan perbincangan atau perdebatan yang menimbulkan kontroversi, artinya ada pihak-pihak yang pro dan kontra ada yang mendukung dan ada yang tidak mendukung. Neolaka $(2019 ; 21)$ mengungkapkan bahwa analisis kebijakan pendidikan dilakukan untuk pedoman bertindak, mengarahkan kegiatan pendidikan, organisasi sekolah atau lembaga pendidikan sebagai penyelenggara dapat mencapai tujuan yang telah di rencanakan.

Analisis kebijakan tentu berpedoman pada delapan komponen Standar Nasional Pendidikan, yang salah satunya adalah membahas standar sarana dan prasarana, apalagi di masa new normal.

\section{Sarana \& Prasarana Sekolah}

Tidak dapat dipungkiri suksesnya pembelajaran disekolah didukung oleh adanya pendayagunaan dan dikelola sarana dan prasarana pendidikan yang ada disekolah secara efektif dan efisien. Menurut Merian $(2021 ; 4)$ memaparkan bahwa keberhasilan suatu program pendidikan melalui proses belajar mengajar sangat dipengaruhi banyak faktor, salah satu di antaranya adalah tersedianya sarana dan prasarana pendidikan yang memadai serta pemanfaatan dan pengelolaan secara optimal. Peraturan Pemerintah No. 19 Tahun 2005 tentang standar Nasional Pendidikan yang menyangkut standar sarana dan prasarana pendidikan secara nasional pada Bab VII Pasal 42 dengan tegas menyebutkan bahwa: 1) Setiap satuan pendidikan wajib memiliki sarana yang meliputi perabot, peralatan pendidikan, media pendidikan, buku, dan sumber belajar lainnya, bahan habis pakai, serta perlengkapan lain yang diperlukan untuk menunjang proses pembelajaran yang teratur dan berkelanjutan; dan, 2) Setiap satuan pendidikan wajib memiliki prasarana yang meliputi lahan, ruang kelas, ruang pimpinan satuan pendidikan, ruang pendidik, ruang tata usaha, ruang perpustakaan, ruang laboratorium, ruang bengkel kerja, ruang unit produksi, ruang kantin, instalasi daya dan jasa, tempat berolahraga, tempat beribadah, tempat bermain, tempat berkreasi, dan ruang/tempat lain yang diperlukan untuk menunjang proses pembelajaran yang teratur dan berkelanjutan.

Begitu pentingnya sarana prasarana pendidikan sehingga setiap institusi berlomba-lomba untuk memenuhi standar sarana dan prasarana pendidikan demi meningkatkan kualitas proses pembelajaran. Sarana dan prasarana disekolah sangat mempengaruhi proses pembelajaran karena sarana dan prasarana yang mendukung dapat membuat siswa melakukan kegiatan belajar mengajar dengan efektif. Sarana dan prasarana menurut Kamus Besar Bahasa Indonesia (KBBI), sarana adalah segala sesuatu yang dapat dipakai sebagai alat dalam mencapai maksud dan tujuan. Sedangkan prasarana adalah segala sesuatu yang merupakan penunjang utama terselenggaranya suatu proses. Dilihat dari fungsinya atau perannya terhadap proses pembelajaran maka sarana pendidikan dibedakan menjadi: alat peraga, alat pelajaran, dan media pengajaran. Selain itu, manajemen lingkungan di dalam maupun di luar sekolah harus dipersiapkan dengan menyiapkan sarana dan prasarana yang mendukung protokol kesehatan.

Megawati dan Rochman $(2020 ; 243)$ mengisyaratkan bawa sarana dan prasarana pendidikan tidak hanya berproses pada pengadaan, namun harus berangkat dari perencanaan, pengadaan, pemeliharaan, inventarisasi serta pengawasan. Tahapan perencanaan adalah suatu proses analisis

Warya Awersendi S. Rumbiak, Witarsa Tambunan 
dan penetapan kebutuhan yang diperlukan dalam proses pembelajaran, kebutuhan primer dan kebutuhan yang menunjang. Tahapan pengadaan merujuk pada semua kegiatan penyediaan sarana dan prasarana untuk menunjang pelaksanaan tugas. Karena fungsi dan kegiatan setiap organisasi berbeda, maka pengadaannya tidak selalu sama. Proses inventaris adalah kegaitan pencatatan terhadap sarana dan prasarana sebagai bentuk kontrol, bukti, dan pengecekan. Proses pengawasan merupakan koordinasi serta akselerasi bagi seluruh fungsi pengelolaan, sehingga pemborosan waktu, tenaga dan biaya dapat dihindarkan.

\section{METODE PENELITIAN}

Masalah penelitian dapat ditemukan melalui study literature atau lewat pengamatan lapangan. Adapun analisis ini menggunakan pendekatan kualitatif dengan penelitian deskriptif yang mana teknik pengumpulan datanya dengan observasi di sekolah, dan telaah pustaka (literature review). Pengamatan dilakukan peneliti tentang sesuatu yang direncanakan ataupun yang tidak direncanakan, baik dalam jangka pendek maupun dalam jangka waktu yang cukup lama, terstruktur atau tidak terstruktur, itu dapat melahirkan suatu masalah. Begitu juga dengan sumber identifikasi masalah. Ranjit Kumar di rujuk oleh Witarsa (2021; ppt 4) mengungkapkan bahwa ada tiga sumber identifikasi masalah, yaitu people and problem, teknik dan program, dan fenomena yang terjadi. Hasil penelitian ini memberikan informasi kepada pembuat kebijakan di SMA Kristen Barana' pertama melakukan analisis yang tepat sasaran dalam menyiapkan sistem pembelajaran tatap muka yang efektif dan aman. Kedua, mengambil keputusan secara bijaksana dalam mengidentifikasi penyiapan sarana dan prasarana yang tepat guna untuk kegiatan pembelajaran tatap muka yang efektif dan efisien, khususnya di masa new normal. Hasil kajian ini diharapkan menjadi tolak ukur bagi sekolah-sekolah yang akan melaksanakan proses pembelajaran tatap muka di era new normal dan sekaligus kajian ini diharapkan untuk diteliti lebih lanjut.

\section{HASIL DAN PEMBAHASAN}

SMA Kristen Barana' yang adalah sekolah berasrama di mana peserta didik, laki-laki dan perempuan mereka tinggal di asrama dalam lokasi sekolah. Jumlah peserta didik ada 513 siswa yang terbagi ke dalam tiga tingkatan (X-XII) yang mana setiap angkatan terdiri 171 siswa dan 32 siswa di setiap kelasnya. Sedangkan jumlah tenaga pendidik, kependidikan, pengurus asrama, ibu dapur sampai satpam berjumlah 92 orang. Jadi total keseluruhan keluarga besar SMA Kristen Barana' berjumlah 623 orang. Dengan jumlah warga sekolah yang ada, tentunya ini peluang secara khusus bagi sekolah untuk melakukan manajemen keuangan dari sumber-sumber pendapatan yang ada, yaitu dari pemerintah, orangtua siswa, usaha sekolah dan Yayasan. Inilah tantangan yang harus diatasi oleh sekolah swasta. Walaupun demikian, Neolaka $(2020 ; 84)$ menjelaskan kajian utama kebijakan pendidikan formal adalah pada UU No. 20 tahun 2003 tentang Sistem Pendidikan Nasional dan Standar Nasional Pendidikan dalam PP No.19 Tahun 2005. Adapun standar nasional pendidikan yang berlaku meliputi komponen-komponen; standar kompetensi lulusan, isi, proses, pendidik dan tenaga pendidik, sarana dan prasarana, pengelolaan, pembiayaan pendidikan dan standar penilaian pendidikan.

Fokus pada tujuan pengadaan sarana-prasarana yang mana mempengaruhi proses pembelajaran dan terlaksananya pembelajaran tatap muka, maka dipandang perlu analisis kebijakan pendidikan yang baik pula sekalipun ada hambatan dan tantangan secara finansial. Contohnya, dari hasil survey pembelajaran tahun ajaran 2020/2021, ada sekitar 50\% peserta didik yang mana orangtuanya terkendala secara finansial sehingga meminta pengurangan biaya sekolah. Di lain, sisi bantuan dari pemerintah pusat mengenai Dana Bantuan Sekolah lambat proses pencairannya, sehingga menggoyahkan finansial sekolah beberapa bulan terakhir di semester dua. Untuk menghadapi situasi ini, sebagai sekolah swasta yang dituntut mandiri, harus memikirkan solusi atas situasi ini. Dengan adanya program entrepreneurship sekolah yaitu usaha loundry, penginapan sekolah, dan usaha peternakan bebek, lele dan perkebunan sayur-sayuran ini tentunya diharapkan mendukung pembiayaan sekolah, namun pada kenyataannya belum cukup.

Warya Awersendi S. Rumbiak, Witarsa Tambunan 
Tentunya ini berdampak pada stabilitas pendapatan sekolah untuk pembiayaan pendidikan secara keseluruhan, apalagi untuk pengadaan sarana dan prasarana di masa new normal yang begitu ketat harus menerapkan protokol kesehatan. Penerapan Protokol Kesehatan (ProKes) tentunya berhubungan dengan perencanaan dan pengadaan sarana dan prasarana yang mana harus disesuaikan dengan kondisi dan keadaan situasi dan kondisi sekolah, baik secara geografis, dan penataan lingkungan sekolah. Untuk lebih jelasnya, kita akan melihat bagaimana dampak dari kurangnya penyiapan sarana dan prasarana di sekolah jika tidak melalui proses analisis kebijakan bagi sekolah yang akan mengadakan pembelajaran tatap muka, dengan memperhatikan gambar pohon masalah dibawah ini.

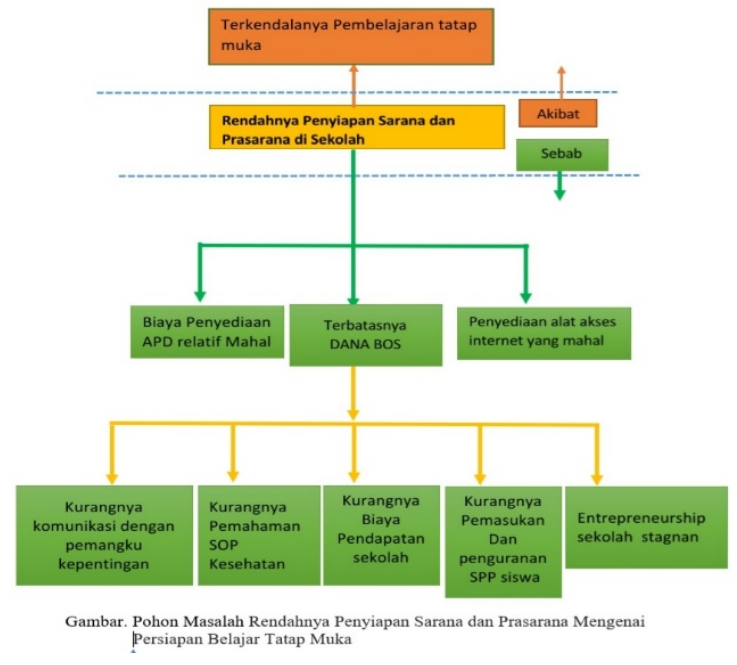

Dari gambaran di atas, kita melihat penyebab rendahnya pengadaan sarana dan parsarana yaitu disebabkan mahalnya Alat Pelindung Diri, Dana BOS yang pencairannya dua kali tahapan sedangkan sekolah harus dengan segera melakukan pembenahan sistem dan penyiapan sarana dan prasarana, serta alat akses internet yang tidak murah. Pada sisi lain, diperlukan data dan gambaran mengenai warga sekolah, fasilitas sarana dan prasarana yang telah ada selama satu tahun ajaran 2020/2021. Berikut dari hasil observasi lapangan berikut tabel gambaran sarana dan prasarana yang ada di SMA Kristen Barana'.

\begin{tabular}{llllllll}
\hline No & Ruangan & Jlh & keadaan & No & Ruangan & Jlh & keadaan \\
\hline 1 & Kepala Sekolah & 1 & Baik & 16 & WC siswa PA & 13 & Baik \\
\hline 2 & WaKepSek & 3 & Baik & 17 & Lap. Basket & 1 & Baik \\
\hline 3 & Tata Usaha & 2 & Baik & 18 & Lap. Volley & 1 & Baik \\
\hline 4 & Bendahara & 3 & Baik & 19 & Lap. Takraw & 1 & Baik \\
\hline 5 & Tamu & 2 & Baik & 20 & Lap. Badminton & 1 & Baik \\
\hline 6 & Bimb. Konseling & 1 & Baik & 21 & Pengurus Asrama & 2 & Baik \\
\hline 7 & Perpustakaan & 1 & Baik & 22 & UKS & 1 & Baik \\
\hline 8 & Lab. Praktikum & 2 & Baik & 23 & Kasur Rawat Inap & 8 & baik \\
\hline 9 & Lab.Komputer & 1 & Baik & 24 & Satpam & 1 & Baik \\
\hline 10 & Aula & 1 & Baik & 25 & Prakarya & 1 & Baik \\
\hline 11 & Asrama Putra & 1 & Baik & 26 & R. makan Siswa & 1 & Baik \\
\hline 12 & Asrama Putri & 1 & Baik & 27 & Dapur & 1 & Baik \\
\hline 13 & Gazebo & 7 & Baik & 28 & Istirahat Pegawai & 1 & Baik \\
\hline 14 & WC Guru & 5 & Baik & 29 & Green House & 1 & Baik \\
\hline 15 & WC siswi PI & 13 & Baik & 30 & Kelas & 16 & Baik \\
\hline
\end{tabular}

Melihat kondisi sarana-prasarana yang ada di atas, dapat kita simpulkan bahwa setiap area memiliki gambaran penyediaan perlengkapan sarana-prasarana yang berhubungan dengan penerapan protokol kesehatan, seperti tempat cuci tangan, penyemprotan disinfektan secara

Warya Awersendi S. Rumbiak, Witarsa Tambunan ANALISIS KEBIJAKAN PENDIDIKAN DALAM PENYIAPAN SARANA DAN PRASARANA PADA PERENCANAAN PEMBELAJARAN TATAP MUKA DI SMA KRISTEN BARANA'| 33 
berjangka, bahkan sampai pada vitamin yang harus di sediakan pihak sekolah di UKS. Di sisi lain, pembenahan spot-spot pemasangan instalasi jaringan internet belum memadai. Di lingkungan asrama, kebersihan dan kenyamanan lingkungan kamar dan WC harus menjadi prioritas sekolah ditambah aturan interaksi siswa selama berada dalam kamar. Maka dari kondisi yang ada, pembiayaan untuk pengadaan sarana kebersihan dan sterilisasi lingkungan sekolah dan belajar adalah mutlak.

Dalam proses pembelajaran belajar dari tahun ajaran 2020/2021, siswa mengeluhkan data bantuan yang tidak dapat digunakan serta akses internet yang ada di lingkungan sekolah yang begitu lemah untuk mengakses bahan pelajaran. Disisi lain, tantangan bagi siswa yang ada di luar asrama, memiliki hambatan untuk memahami materi ajar yang diberikan oleh pendidik. Dari hasil observasi ini, dapat disimpulkan bahwa sekolah masih memiliki "pekerjaan rumah" dalam merencanakan dan mengadakan sarana-prasarana khusus internet access. Sehingga pada perencanaan pembelajaran tatap muka di setiap sekolah untuk tahun ajaran baru sesungguhnya harus melalui tahapan proses analisis kebijakan pendidikan dari level pusat sampai ke sekolah.

Analisis Kebijakan pendidikan tentu memiliki fungsi dan tujuan untuk memecahkan persoalan, dan masalah yang begitu kompleks. Sehubungan dengan latar belakang masalah, maka pada gambar selanjutnya kita akan melihat target yang diupayakan melalui analisis kebijakan yang digambarkan melalui pohon sasaran bagaimana sekolah dapat mewujudkan proses pembelajaran tatap muka yang tetap mengikuti protokol kesehatan. Untuk sampai para sasaran atau tujuan yang ingin dicapai, dibutuhkan step-step kerja yang baik dan benar, kordinasi dan komunikasi yang terbuka untuk mencapai solusi bersama secara konsisten dan hati-hati, serta motivasi dan usaha yang tentunya diharapkan akan menghasilkan pendapatan sekolah secara khusus.

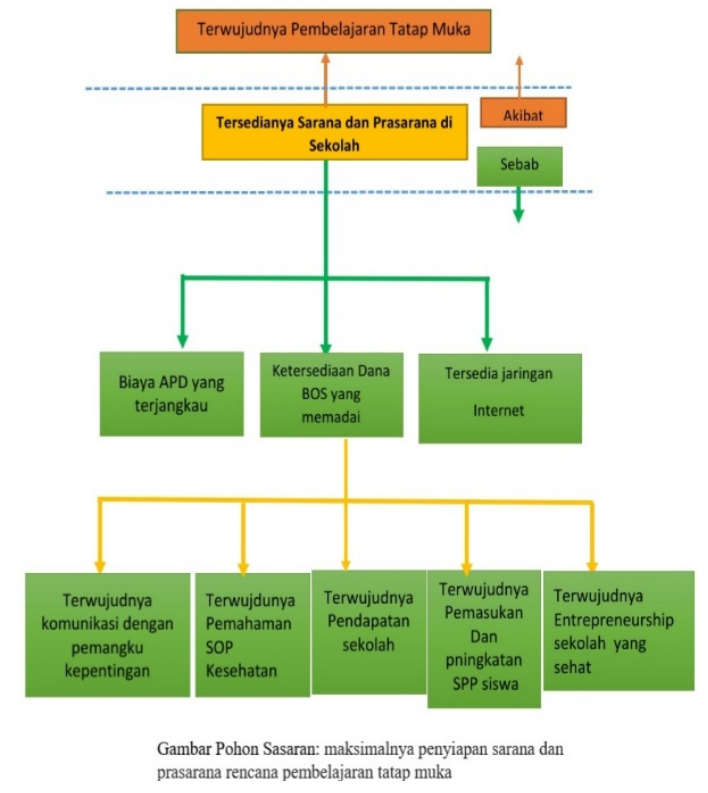

Gambaran di atas menunjukkan bahwa jika Dana BOS mampu dimanfaatkan secara bijaksana, dan para pegawai mampu meningkatkan motivasi dan semangat usaha sekolah, serta membuka komunikasi yang efektif dengan para sumber donatur sekolah maka diharapkan pendapatan tetap sekolah dapat merealisasikan pengadaan sarana dan prasarana untuk pelaksanaan pembelajaran tatap muka. Berikut gambar pohon alternatif sebagai upaya proses analisis kebijakan pendidikan dalam rangka penyiapan sarana dan prasarana di sekolah dalam persiapan pembelajaran tatap muka. 


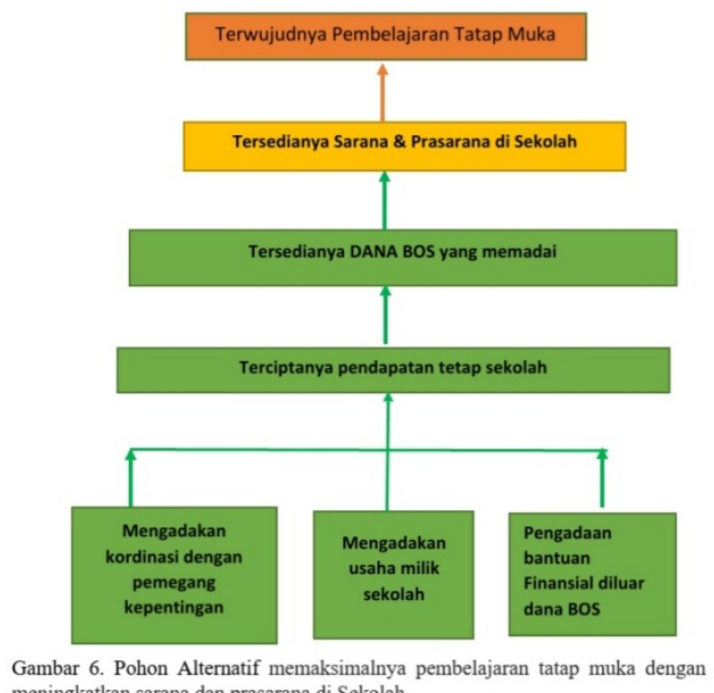

Dari gambaran pohon alternatif diatas, dapat kita simpulkan bahwa dengan ketepatan tersedianya dana BOS, bantuan yayasan, orangtua yang memadai serta melalui usaha sekolah maka penyiapan sarana dan prasarana dapat terwujud sehingga pembelajaran tatap muka dapat dilaksanakan. Kordinasi, komunikasi yang efektif, dan adaptif sangat perlu dibangun oleh setiap pemegang kebijakan dalam interaksinya. Di sisi lain, sebagai sekolah swasta, kegiatan entrepreneurship merupakan program yang harus dirintis dan dikembangkan dalam rangka mendukung pembiayaan sekolah.

Proses analisis kebijakan pendidikan harus dilaksanakan secara terbuka dengan komunikasi yang efektif antar pihak Yayasan dan Sekolah, bahkan dengan Dinas Pendidikan bahkan Pemerintah Daerah untuk kemungkinan pengajuan bantuan penyiapan sarana dan prasarana sekolah. Komunikasi yang efektif dengan orangtua siswa perlu dilakukan untuk membangun kesepahaman dan dengan tujuan untuk saling menopang dalam soal pembiayaan pendidikan. Ini dikarenakan jika organisasi sekolah tidak melakukan proses analisis kebijakan mengenai penyiapan sarana dan prasarana sekolah maka sulit untuk memberlakukan sistem pembelajaran tatap muka di kelas. Bintang R. Simbolon dalam tulisan M. Allo dan Yusuf Rombe $(2019 ; 42)$ menyatakan bahwa organisasi yang baik itu adalah organisasi yang bergerak secara harmonis, maka tentulah dalam hal ini yang berperan adalah membangun sistem komunikasi dalam organisasi.

\section{KESIMPULAN}

Terwujudnya pembelajaran tatap muka sesungguhnya bergantung pada sejauh mana sekolah melalui analisis kebijakan pendidikan menguraikan dan mengidentifikasi sarana dan prasarana yang perlu harus dipersiapkan untuk proses pembelajaran tatap muka. Pemerintah pusat melalui kebijakannya harus mampu mendelivery bantuan kepada sekolah-sekolah dengan tepat guna sebagai bentuk perhatian serius dan bentuk tanggungjawab memperlengkapi dan mencerdaskan kehidupan bangsa, sekalipun di masa pandemi. Di sisi lain, sebagai sekolah swasta, diperlukan suatu upaya untuk meningkatkan kemandirian pembiayaan sekolah dengan menciptakan berbagai usaha sekolah dengan membuka peluang usaha untuk kepentingan kemandirian internal sekolah. Saran penulis, sekiranya kordinasi dan ruang komunikasi yang intens antar pemegang kebijakan dapat terjadi, sehingga melalui pertemuan tersebut terbangun kondisi yang mana memberikan kesempatan bagi sekolah untuk mengajukan pertolongan yang sekiranya dapat di bantu oleh pemerintah daerah maupun dari kalangan donatur tetap sekolah, misalkan dengan yayasan yang bertanggungjawab. Pemimpin sebagai leader diharapkan mampu menganalisis peluang dalam membuka usaha atau entrepreunership sekolah yang mana diharapkan dapat mem-back up 
pembiayaan sarana dan prasarana sekolah Leadeship kepala sekolah sangat menentukan bentuk dan proses analisis yang ditempuh. Pada akhirnya, kebijakan Kepala Sekolah juga harus mengupayakan kerjasama yang bersumber dari orangtua, pemerintah, usaha sekolah dan Yayasan yang membawahi dalam mendukung pengadaan sarana dan prasarana yang dibutuhkan.

\section{DAFTAR PUSTAKA}

1. Allo, M., Yusuf Rombe .(2019). Pemimpin Yang Kredibel Dan Yang Bervisioner. Fundamental Manajemen Journal, 4 (1). pp. 22-36. ISSN 25409220

2. Hanisy, A. (2013). Konsep dasar analisis kebijakan. Al Qodiri: Jurnal Pendidikan, Sosial dan Keagamaan, 4(1), 48-63.

3. Megawati, M., \& Rochman, C. (2020). Analisis Ketercapaian Standar Sarana dan Prasarana pada Sekolah Menengah Pertama di Bekasi. Al-TA'DIB: Jurnal Kajian Ilmu Kependidikan, 12(2), 240258.

4. MERIAN, P. (2021). MANAJEMEN SARANA DAN PRASARANA PENDIDIKAN DI MTS NEGERI 1 LAMPUNG BARAT (Doctoral dissertation, UIN Raden Intan Lampung).

5. Novianti, E., Fatkhia, A. R., \& Nuryana, Z. (2020). Analisis Kebijakan Pembelajaran PAI di Masa Pandemi: Peluang Dan Tantangan. Jurnal Pendidikan Islam, 11(2), 201-212.

6. Nissa, S. F., \& Haryanto, A.(2020). Implementasi Pembelajaran Tatap Muka Di Masa Pandemi Covid-19. Jurnal IKA PGSD (Ikatan Alumni PGSD) UNARS, 8 (2), 402-409.

7. Nurochim, N., \& Ngaisah, S. (2020). Organisasi Sekolah di Masa Pandemi. Alignment: Journal of Administration and Educational Management, 3(2), 154-167.

8. Neolaka, I. A. (2019). Isu-isu kritis pendidikan: utama dan tetap penting namun terabaikan. Prenada Media.

9. Tambunan, W.2021.Materi Kuliah Analisis Kebijakan dan Pengambilan Keputusan Pendidikan; Analisis Kebijakan Pendidikan. Ppt pertemuan 2. Rabu,17.00-19.45

10. Tambunan, W.2021.Materi Kuliah Analisis Kebijakan dan Pengambilan Keputusan Pendidikan; Isu dan Masalah dalam Analisis Kebijakan Pendidikan.Ppt pertemuan 5. Rabu, 17.00-19.45

11. Utami, I. H., \& Nasution, U. (2020). Kebijakan Kepala Sekolah dalam Meningkatkan Mutu Melalui Manajemen Peserta Didik. Al-Idarah: Jurnal Kependidikan Islam, 10(1), 46-52.

12. Widodo, J. (2021). Analisis kebijakan publik: Konsep dan aplikasi analisis proses kebijakan publik. Media Nusa Creative (MNC Publishing).

Warya Awersendi S. Rumbiak, Witarsa Tambunan 